\title{
IISAE \\ EVALUATION OF THE IMPLEMENTATION OF NATIONAL EDUCATION STANDARDS ON ANTECEDENT COMPONENTS IN SPECIAL OF VOCATIONAL HIGH SCHOOL
}

\author{
Ema Noviah \\ Universitas Negeri Jakarta \\ emanoviah_pep17s2@mahasiswa.unj.ac.id \\ Aip Badrujaman \\ Universitas Negeri Jakarta \\ aip.bj@unj.ac.id \\ Wardani Rahayu \\ Universitas Negeri Jakarta \\ Wardani9164@yahoo.com
}

\begin{abstract}
The children's Special Correctional Institution (LPKA) on Tangerang City is one of the institutions that organizes the form of coaching Vocational High School (SMK). Implementation of education in Vocational High School must meet the minimum criteria in accordance with national education standards. Learning planning, educator qualifications and infrastructure is one of the components that exist in the national standard of education. This research aims to evaluate the quality of Lesson Plan (RPP) and assessment, educator qualifications, and infrastructure in the antecedent component of the Concatenate stake model in Special of Vocation High School. This research is an evaluative research with a qualitative approach. The method of data collection used in the form of interviews, documentation studies, and observations with the validity technique of data research results using the credibility by prologue engagement, persistent observation, and member checking. The results showed that educators first did not prioritize Learning Program Planning and its assessment, both lacking facilities of learning infrastructure, and all three educators who did not have a certificate of educators.
\end{abstract}

Keyword: Antecedent component, evaluation, the children's Special Correctional Institution (LPKA)

\section{INTRODUCTION}

Education is an important role because through education, one is able to develop cognitive skills, attitudes and skills that can be used to solve problems in everyday life. In the correctional system conducted by several countries such as Scotland, United States of America, the states of the United Kingdom (UK), and Indonesia, placing an education program into a coaching program must be held as a form of The fulfillment of fundamental prisoners of human rights (Brazzell, Crayton, Mukamal, Solomon, \& Lindah, 2009; Cale et al., 2018; Justice's, 2016). This is in accordance with the results of the meta analysis conducted by Sulhin (2017) showing $84 \%$ of countries around the world conducting educational programs in correctional institutions (prison), in order to develop talents, abilities, and skills Prisoners to live life after completing the detention period. 
With the education in the prison is expected to minimize prisoners back to the prison (Bozick, Steele, Davis, \& Turner, 2018; Esperian, 2010; Silvestri \& Wdizioni, 2013). MacDonald, (2018), Novian et al., (2018), and Urombo \& Kasimba, (2018) stated the main factor resulting in the return of prisoners to the prison is the maximum fulfillment of prisoners ' rights and the lack of effective coaching function especially in terms of Education. In fact, according to Meissner \& Jourdan, (2017) well-organized education and training in prison, can suppress the incidence of residivisme, build work experience, reduce the risk of mental illness, improve prison safety, provide financial income for prisoners who are able to develop skills from the program that follow, and have a greater chance to get the job after completing the detention period (Esperian,2010; Formon, Schmidt, \& Henderson, 2017). The government of Indonesian has compiled the construction activities stipulated in the law with the foundation of the philosophy of Pancasila as the nation's ideology, to be applied in the construction of convicts throughout the prison (Najih, 2018; Utami, 2017). different with the Scotland and the UK countries, who prefer to carry out coaching based on the needs and desires of the prisoners. According to Coyle (1998), Crime (2017), and Duwe (2017) both things are legitimate. Because each country has a model of convict formation that is adapted to the cultured, and the urgensity of each crime is still referring to the standards of convict construction in the rules of treatment of prison (Hayes \& Blunt, 2011).

\section{Antecedent Components on Evaluation Model Countenance Stake}

The evaluation Model of the Countenance Stake has a framework often used in conducting an evaluation activity. The three dimensions consist of Anteceden, transaction and outcome (Vanitha Thanabalan, Siraj, \& Alias, 2015). The meaning of antecendents (Jody L. Fitparick, Sander, and Worther, 2004:134-135) in (Stake: 1967) is an input, condition, and any resources that can support the implementation of the program. Lukum (2015) further interactively when all conditions, resources and inputs that existed before the implementation of the program, not only can support the implementation but also have a related or direct impact on the outcome of the program. (Gerald F. Draayer, 2009 and Siswanto, 2019) explained that if the form of antecendent itself could be a written document about a breakdown of planning or resource components of a program. Which, if described in the context of learning, can be Lesson Plan, infrastructure, and educator qualifications (Bendriyanti \& Dewi, 2014; Lukum, 2015; Zulfiati \& Kurniawati, 2018).

\section{Vocational high school in the Environtment children's Special Correctional Institution (LPKA) of Tanggerang City}

LPKA Tangerang city is one of the institutions of the sub-criminal justice system that organizes vocational high school education programs. The purpose of the program is not merely realizing government regulation or the implementation of intellectual coaching for prisoners. However, it provides the living provision that the child can use after running the detention period and minimizing the chances of the child's recidivism. 
The Government of the Republic of Indonesia has determined that the education of vocational school must meet the minimum criteria in accordance with the national standards of education. Among them are process standards, education standards and educational personnel, standards of facilities and infrastructure, also the education assessment standards.

In the results of interviews with the head of the education field of LPKA Tanggerang city said that the Vocational High School program is the most demanding program. Due to the average age of students the prison (Andikpas) ranges between 15-18 years or the age of the child at the secondary level of education. Nevertheless, the program that was established since 2013 has not been able to answer the anxiety of the prison students facing the outside world after completing the detention period.

Shinkfield \& Graffam (2010) argued that the anxiety suffered by child prisoners tends to be higher than that of adult convicts. This is because, the first child prisoners have no life experience that has to be used to serve after completing the detention period. Both have excess concerns on the sanctions and negative stigma of the public against him. Third is the discrimination of various parties that seems to make it a disarray and become invaluable. If these three things happen, then it indirectly gives the child the potential to become a resident. Because the average age of Andikpas was in the self-discovery phase, which required the role of family, and the surrounding environment, in the formation of character and concept of himself (Pasupathi \& Mclean, 2012).

Based on the results of observation and interviews with one of the internal teachers (GI. 1), obtained information if during the seven years of the school vocational standing, only a small portion of graduates are absorbed in the industry world DU/DI. Furthermore, other sources (GI. 2) also said, although the absorption of vocational school graduates in DU/DI is still very minimal, but the total number of graduates who work is estimated to reach fifty percent. Although the work that is in the habit does not match what is learned.

Low the absorption of vocational high school graduates in DU/DI as well as the high anxiety of children in the face of liberation, showing the achievement of the competency standards of school graduates with good vocational in the learning conducted by special of vocational high school. Rahmawati \& Anggraini (2017) and (Sajidan, Baedhowi, Triyanto, Masykuri, \& Mohammad, 2018) stated that if there is no achievement of the competency standards well in a study, indicating that there is an ineffectiveness of the implementation of the learning process in the classroom. This is because the learning process serves as a deciding factor that can control the success of the learning process.

Ibrahim \& Mohamed (2017) and Bell (2015) said when the implementation of good learning will be positively correlated with planning. The good practice of learning is a sign when the preparation of learning planning is also done optimally. Alawamleh, Bdah, \& Alahmad (2013), Németh \& Long (2012), and Arnold (2015) Learning planning is one of the factors that determines the quality of teaching. The structured learning plan allows the teacher to explore the skills of the students, either in the knowledge, attitudes, or skills (Shen, Poppink, Cui, \& Fan, 2007). 
Furthermore, Relisa (2016) argues that when low quality of graduates is not only a result of the lack of maximal learning planning, but also by insufficient school support resources such as educators and facilities infrastructure.

The Evaluation Model is compiled by stake to place the suspected problems that is experienced by Special Vocational Schools in the antecedent dimension. it is an indicator to explain the components of the preparation of learning planning, infrastructure, and educator qualifications, as in the research is conducted by (Motondu \& Rusyadi, 2017; Siswanto, 2019; Wahab \& Kholis, 2017).

Based on this, this study aims to look the effectiveness of antecedents in the learning program implemented by Special Vocational Schools in the correctional institution environment. The novelty in this research is the use of a stake countenance model that is considered appropriate to study the problem, and has never been used to see the effectiveness of learning carried out by the Tangerang correctional institution for children especially in the Special Vocational Education program.

\section{METHOD}

This research was conducted at LPKA Tangerang city for 9 months. This research is a evaluative study using a qualitative approach and a special model countenance stake in the antecedent component. According to Kielmann, Cataldo, \& Seeley (2012) Qualitative is an approach to naturalistic research that tries to explore social issues naturally and scientifically through a complex and holistic picture. Conducting data searches based on causal consequences (Liu \& Zhang, 2015). The speakers involved in the study were teachers and alumni of vocational high school with data collection methods in the form of interviews, documentation studies and observations. The techniques used to maintain the validity of the data are credibility, in prologue engagement, persistent observation, and checking members.

\section{RESULTS}

Based on the results of interviews, observations, and documentation studies, the antecedent component in the evaluation model used to determine the quality of the learning and assessment planning, infrastructure and educator qualifications.

\section{Preparation of Lesson Plan}

Based on the results of interviews conducted with external teachers (GE) and Internal teachers (GI), obtained information that special of vocational high school implemented the 2013 curriculum (K13) on learning activities. Referring to the regulation of the minister of Education and culture of Indonesian number 65 year 2013, learning planning in K13 is designed in the form of syllabus and lesson plan tailored to the process standard. The following data is interviewed by internal and external educators to explore information about the preparation of lesson plan.

"If talking about lesson plan be honest is one thing that we do not prioritize. Because if it follows the standard Rules and curriculum 
standards 2013, it cannot be applied there in time”. (GE. 1 \& GE.

2)

The statements of GE. 1 and GE. 2, in line with the answers of GE. 4 and GI. 2 on the preparation of RPP conducted for the learning activities. The following are the speakers:

"I do not putting the lesson plan in the learning that I do here, because in addition to the study time is not appropriate standards, the first high school parties special can not force teachers to complete the administration of learning. From the beginning there is no agreement that the teacher should prepare $A, B, C, D$. Sentence always "up to mother or father only". (GE. 4)

"I'm not putting up RPP because I don't understand". (G 1.2)

According to the results of interviewees, there are several factors affecting vocational high school educators not prioritizing the preparation of RPP in learning. Among them are: First, underdeveloped learning administration by internal teachers, because most of them are prison warden which is set in noneducational backgrounds. Second, The implementation of K13 is considered to be less appropriate by external teachers, because LPKA Tangerang city only allocates four days of study time in one week, with the duration of three to four hours each day.

Based on the explanation, it can be concluded that the information conveyed by the informant proves its truthfulness. Researchers added data on observations made from March to May 2019 on the cause of the lesson plan. Among them are: first, teachers are required to customizes learning programs with prison rules that are assessed as less motivated by students with restrictions on the use of information and communication technology (ICT) because it conflicts with Regulation of the Minister of Law of HAM RI number 6 year 2013.

Davis \& Tolbert (2019) and Michals \& Kessler (2015) stated that it was in fact limiting educators ' space to implement a standardized teaching and learning process.

The second is the low motivation to learn Andikpas resulted in the scientific approaches that apply in K13 such as: observing, asking questions, seeking answers to questions, implementing discussion results, and creating a product Based on learning done, cannot be implemented according to scientific learning approaches. The orientation of Andikpas learning is not to increase curiosity and develop abilities. But it meets the rules of coaching established by the institution.

Third is a difficult-to-predict class condition demanding teachers always use more than two learning strategies. It is done to keep the concentration of children who tend to be more active moves than to think to remain steady until the learning activities end. Fourth is a lack of teaching personnel, causing the learning process to become not conducive. This is because the tenth (X) and eleven (XI) classes are often merged into one during the learning process. The situation often makes teachers difficult to determine, organize and develop teaching materials. Michals \& 
Kessler (2015) states that when the conditions of merging between classes make the learning process ineffective. Some prisoners who suffered a similar condition gave an objection response because the given differentiation material was continuously repeated and was less likely to increase (Eikeland \& Asbjørnsen, 2009).

The difficulty in implementing K13 learning planning was previously revealed by GI. 1 on the Fourth of January 2019. According to him, the implementation of K13 for learning in prison environment needs to be studied more seriously. This is because the curriculum is not able to answer the need for learning Andikpas. The exposure was similar to the opinions of Bruyns \& Nieuwenhuizen (2003), stating that the education and coaching carried out in the prison should be adjusted to the situation, condition, and needs of the convicts.

The interviewer's statement at the time of the interview on the not-in-learning activity is not in accordance with the documentation of the study results obtained on January 26, 2019. Researchers obtain lesson plan physical evidence from one of vocational high school internal educators. After thorough assessment and analysis of the document, it was shown that the lesson plan was not drafted by educators.

Lesson plan is no-one in teaching suggests that vocational high school educators do not devise aspects of the trumpet on learning. However, in the implementation, there are learning assessments conducted by the teachers only to measure the competency of the students in terms of knowledge. Due to assessment of attitudes and skills carried out by internal officers prison.

Sourced from interviews with some of the external educators, such as GE. 1, GE. 2 and GE. 3 obtained the information that teachers who teach at the vocational high school are doing the assessment. However, the assessment is only limited to the assessment using written tests to measure students ' knowledge. Proving the truth of the information, researchers directly clarified the data using the technique of member checking on other sources or GE. 4. Here are the speaker answers when they are given questions about the learning assessment.

"I tried to do another assessment besides the student's knowledge, but finally when I did it I was very confused. Because I think, I have here only a few hours and it's only 1 once in 1 week" (said GE. 4)

In accordance with the information that was previously obtained, GE. 4 as the last interviewee, gave a description that if most of the external teachers of vocational high school give the authority to assessment of skills and attitudes Children. Internal parties such as children's guardians or internal educators. As a party that considers closer to the child both in terms of time and personal. In accordance with the information that was previously obtained, GE. 4 as the last interviewee, gave a description that if most of the external teachers of vocational Middle school give the authority to assessment of skills and attitudes Children. Internal parties such as children's guardians or internal educators. As a party that considers closer to the child both in terms of time and personal.

"We are only doing the knowledge assessment. As for the assessment of children's attitudes we submit to the internal parties 
who know and have a lot of time with children. As for the practicum assessment we adopted it from the industrial world" (said GE. 1 \& GE. 2)

Ifeanyichukwu \& Abuchi (2015), Branch (1995) states that the limitation of learning time is the biggest challenge and obstacle in the field of education in the prison. It is caused by coaching that is carried out in the prison not only of education, but rather skills, spirituality, and health that requires space and time in its application.

Assessments conducted by external teachers are not limited to assessments to measure students ' knowledge. Especially for vocational subjects, for example, automotive teachers conduct skills assessment directly to measure students ' skills in practical activities in the workshop. Although the assessment instrument used is an instrument adopted from the industrial world.

\section{Facilities and Infrastructure}

According to Barrett, Treves, Shmis, Ambasz, \& Ustinova (2018) facility is an important indicator that can support the implementation of the learning to be maximal. LPKA Tangerang City has a sturdy building condition, stable, avoid interference from environmental pollution and air pollution. This is because since the beginning of the building of LPKA Tanggerang City, it has been served as a place of exile for children of Dutch descent who violate the rules and norms that are in the community. The history writes, if the place was built in 1925 and had undergone the function of being the IV Regiment headquarters in the year 1945, it became the wrong cultural heritage that is still being enabled to date. Based on observation results, LPKA Tanggerang city located at Jl. Tmp. Taruna No. 29C, RT. 001/RW. 001, Sukaasih, Tangerang Sub-district, Tangerang City, Banten Province, Postal code 15111. Provide seven special spaces that can be used for the implementation of vocational high school education with the following details:

\section{Study Room}

Special of Vocational High School has three classrooms that serve as a place for teaching and learning activities, both theoretical and practical. Each room is $100 \mathrm{~m} 2$ with a total of 38 students, divided into three learning groups. Among them are: The tenth class there are four students, the next class there are seven students and the twelfth class there are twenty-seven students.

Referring to ministerial regulation number 40 year 2008, middle school classrooms that are in the environment LPKA Tanggerang City has fulfilled the minimum standards of study space specified is $2 \mathrm{M} 2 /$ students for groups of study less than 16 people, with a minimum area of $32 \mathrm{~m} 2$ and $4 \mathrm{~m}$ width. Here's a list of inventory in vocational high school classrooms.

Table 1. Room Inventory Vocational High School

\begin{tabular}{|c|l|c|c|}
\hline No & $\begin{array}{c}\text { Listing of } \\
\text { Item }\end{array}$ & Amount & Condition \\
\hline 1 & White & 1 & Good \\
\hline
\end{tabular}




\begin{tabular}{|c|c|c|c|}
\hline & board & & \\
\hline 2 & $\begin{array}{l}\text { Teacher's } \\
\text { table and } \\
\text { chair }\end{array}$ & 1 & Good \\
\hline 3 & $\begin{array}{l}\text { Student's } \\
\text { table and } \\
\text { chair }\end{array}$ & Conditional & Good \\
\hline 4 & $\begin{array}{l}\text { President } \\
\text { and Vice } \\
\text { President } \\
\text { photos }\end{array}$ & 1 & Good \\
\hline 5 & Styrofoam & 1 & Good \\
\hline
\end{tabular}

Based on the data listed in Table 1, special of vocational high school does not have classrooms with various facilities. This is because all the learning facilities in the classroom will be adjusted to the number of students and the provisions that apply in LPKA Tangerang city. LPKA has procedures that govern forms supporting the construction activities. One of indicator of the procedure is that there must be stable, strong, and safe. The goal is to avoid the occurrence of harmful things, given that children become students in coaching activities, are children with high emotional levels and low self-control (Brazzell et al., 2009; Krezmien, Mulcahy, \& Leone, 2008).

Based on the results of the evaluation conducted by referring to the rules of the minister, if the learning facilities in the classroom vocational high school not yet meet the standards that apply. This is because there are many supporting facilities that are not available in the classroom based on the prevailing government regulations.

The following is the opinion of the speaker, based on the results of the interview as a form of validation so that it can strengthen the evaluation data about the condition of learning facilities existing in SMK special.

"The facilities and infrastructures are very lacking in supporting the implementation of the learning". (said GE. 4/SPP/IV/Friday August, 16 2019)

"The learning I did I distinguish with formal education in general, because the facilities and infrastructures that are there is less complete and less supported so it is difficult to be distributed". (said GE. 3/SPP/IV).

Extracting information through an interview activity is not limited to being conducted on the teacher as a subject in research. Researchers added the opinion of alumni of vocational high school $(\mathrm{ExN})$ who still complete their prisoners in prison, regarding the completeness of learning facilities at special of vocational high school ExN/SPP/Iv. 
"A lack of infrastructure learning facilities especially for library

books that are less up to date. In addition there are no projectors

such as Senior High school outside make learning feels saturate "

Based on the narrative of the teachers and alumni, the picture when the vocational high school that is in the environment of the LPKA Tangerang city, is still experiencing less facility supporting learning. Internal Vocational High School is openly explained to researchers, if the condition occurs because the existing operational budget is not able to meet the needs of school managerial. This is due to the focus of the funding of SMK special not only centered on the needs of the school, but also on the needs of the Andikpas as the following informant statement.

"Not wanting to complement, only the funds are not enough, because the funds available are not only used to complement the needs of the school, but also the needs of our other children who bear". GI. 1/SPP. RB/IV.

The exposure expressed by the speakers, is similar to the results of research conducted by Bruyns \& Nieuwenhuizen (2003) and Edwin (2018) stating if most of the educational activities held in the prison experienced lack of learning facilities.

\section{Learning Support Space}

LPKA Tanggerang city provides not only classrooms to facilitate student learning activities. There is another supporting space that is given to be used as a management place for SMK learning, outside the study room, which is the form of teacher room and administration that becomes one with the headmaster room, and also the automotive workshop room function as a practice laboratories.

Russell \& Weaver (2008), Prabha (2016) argues, in general, the role of practice laboratories in schools can help students to have a meaningful understanding of the concepts of the things being learned. And increase the interest and motivation of students to continue to learn, cultivate thinking skills, as well as the ability to solve the problem scientifically.

The prevailing ministerial regulation stipulates, ideally facilities of vocational high school education are not limited to classrooms, workshops, and governance halls. There are other infrastructures that must be available to support the implementation of learning more effective. Among them are the health unit room of students, places of worship, counseling, libraries, warehouses, to the sanitation room.

Based on the results of the observation, all the facilities are available in the LPKA. The function and size are also adjusted to the capacity of prison occupants. This is because all facilities are built with the purpose of supporting the implementation of construction activities in the prison and not specifically intended for vocational high school of students.

\section{Educators}

Based on the study data, Vocational High School has 18 educators who are divided into two categories, namely: internal educators with 13 people and external 
educators with a total of 5 people. Internal educators are prison officers who are tasked with teaching teachers outside of their duties as correctional guards. While external educators are senior high school education teachers, who volunteer to devote themselves to being a penitentiary. Based on the data, it is seen when Vocational High School educators are more dominated by the internal teachers, which tend to be in non-educator backgrounds and yet have a certificate stating that they have pedagogic competence.

Ensuring the correctness of the data gained, researchers re-conducted interviews with educators in different spaces and times.

"If an external teacher must all have a certificate or legalities of teaching. Because they have a backdrop of education and have a teaching experience long enough. In addition, the average status of civil state apparatus. But if the internal teachers most graduates are non-educational. So we do not have a certificate or legality of teaching”. (said GI. 2)

Based on the results of the evaluation, can be concluded if most of the educators who are in Special of Vocational High School have not been able to provide education and teaching services. Because, the educators do not have a certificate of teaching as a valid proof signifying having mastered the qualifications and competence of educators in accordance with the Law regulation of the Republic of Indonesia number 14 year 2005 about teachers and lecturers.

According to Makovec (2018), Maphoso \& Mahlo (2015), Musau \& Abere (2015), and Palardy \& Rumberger (2015) Qualification and competence are important things an educator must have. Because considering the profession has a responsibility to develop all the potential and ability of learners as a generation of nations. According to Bhatti (2010), Xhemajli, Cyril, \& Methodius (2016) and Vandeyar, (2017) Caena (2014) Xhemajli et al (2016) When educators have more complex roles beyond their duties as teachers, also directing and giving learning facilities so that the learning process is adequate.

More detailed data retrieval is made to get information on the cause of the recruitment of educators with appropriate qualifications to optimize learning.

GI. 1 as interviewed interviewees said, it is already conducting the search activities of educators with appropriate qualifications. But apparently not few of them are resigned slowly after learning the situation and conditions of education held in prison.

The statement is justified by one of the external educators, who also play an active role in the establishment of Vocational High School in prison and said:

"It has often been inviting teachers to help teach in prison. Initially, the teachers were enthusiastic, but as long as time went by they left themselves without any other". (said GE. 1)

Michals \& Kessler (2015) and Patrie (2017) declare when an educator who teaches in a penitentiary, must have a sensitivity to justice and a high social spirit. Because teachers of prison will face different situations than formal education in 
general. With these two things, it is hoped that they can become a motivation capable of growing loyalty teachers in prison teaching.

Referring to the field findings on the conditions of special of vocational high school learning in the prison, evaluation conducted: First, special of vocational high school still experienced a shortage of educators who can support the learning process. Second: Educators are dominated by the competent prison warden who are not qualified as an educator. Third, referring to the law number 14 year 2005 Article 1 paragraph 9 about the duties, principal, and function of teachers and lecturers as professionals, based on competence and appropriate qualifications, most of special of vocational high school teachers, have not fulfilled Predefined standards. It shows that if there is still needed improvement and development for the educators who teach in the prison environment.

\section{CONCLUSION}

Referring to the evaluation, it can be contributed that the study at vocational High school in the environment of the LPKA Tanggerang city has not been carried out effectively. It is reflected by: First; the availability of RPP which is one of the successful factors for the implementation of the learning program by educators. Second; no aspect of judgment on the lesson plan. But in its execution, the assessment carried out by the teacher only a written and assessment of the attitude. And skills carried out by prison internal officers. Third; Infrastructure has not been able to support teaching and learning activities because the school still has a shortage of funding sources. Fourth; Educators who teach in vocational high schools are dominated by internal educators who have not yet been certified educators.

\section{REFERENCES}

Alawamleh, H. S., Bdah, A., \& Alahmad, N. (2013). The Impact of Planning on the Quality of Educational Programs at Al- Balqa 'Applied University. International Journal of Business Administration, 4(5), 38-50. https://doi.org/10.5430/ijba.v4n5p38

Arnold, V. D. (2015). Planning for effective instruction. https://doi.org/10.1080/08878738809554938

Barrett, P., Treves, A., Shmis, T., Ambasz, D., \& Ustinova, M. (2018). The Impact of School Infrastructure on Learning. https://doi.org/10.1596/978-1-4648$1378-8$

Bell, L. (2015). Strategic planning and school management : Full of sound and fury , signifying nothing? https://doi.org/10.1108/09578230210440276

Bendriyanti, R. P., \& Dewi, C. (2014). MO DEL “ COUNTANANCE STAKE " DALAM EVALUASI. In Seminar Nasional Riset Inovatof II (pp. 134-139).

Bhatti, G. (2010). Learning behind bars: Education in prisons. Teaching and Teacher Education, 26(1), 31-36. https://doi.org/10.1016/j.tate.2009.06.020 
Bozick, R., Steele, J., Davis, L., \& Turner, S. (2018). Does providing inmates with education improve postrelease outcomes? A meta-analysis of correctional education programs in the United States. Journal of Experimental Criminology. https://doi.org/10.1007/s11292-018-9334-6

Branch, U. N. O. at V. C. P. and C. J. (1995). Basic Education In Prison. USA.

Brazzell, D., Crayton, A., Mukamal, D. A., Solomon, A. L., \& Lindah, N. (2009). From the Classroom to the Community during Incarceration and Reentry. (T. U. Institute, Ed.). new y.

Bruyns, H. J., \& Nieuwenhuizen, C. (2003). The role of education in the rehabilitation of offenders. sajhe. https://doi.org/10.4314/sajhe.v17i2.25293

Caena, F. (2014). Teacher Competence Frameworks in Europe : policy as discourse and policy as practice. European Journal of Education, 49(3), 312-330. https://doi.org/10.1111/ejed.12088

Cale, J., Day, A., Casey, S., Bright, D., Wodak, J., \& Baldry, E. (2018). Australian prison vocational education and training and returns to custody among male and female ex-prisoners: A cross-jurisdictional study. https://doi.org/10.1177/0004865818779418

Coyle, A. (1998). A Human Rights Approach to Prison Management. South Africa.

Crime, U. N. O. on D. and. (2017). Addressing the global prison crisis Strategy 2015-2017. Australia.

Davis, L. M., \& Tolbert, M. C. (2019). Evaluation of North Carolina 's Pathways from Prison to Postsecondary Education Program. (R. Corporation, Ed.). California.

Duwe, G. (2017). The Use and Impact of Correctional Programming for Inmates on Pre- and Post-Release Outcomes. U.S Departement Of Justice, 1-39. https://doi.org/10.1016/S0167-2991(98)80918-X

Edwin, M. (2018). From Mass Incarceration to Mass Education: Fostering Collaboration Between State Prisons and State Universities. University of New York.

Eikeland, O.-J., \& Asbjørnsen, T. M. og A. (2009). Prisoners 'Educational Backgrounds, Preferences and Motivation. (J. Koefoed, Ed.). Denmark.

Esperian, J. H. (2010). The Effect of Prison Education Programs on Recidivism. Correctional Education Association, 61(4), 316-334. https://doi.org/10.2307/23282764

Formon, D. L., Schmidt, A. T., \& Henderson, C. (2017). Examining Employment Outcomes of Offender and Nonoffender Vocational Program Graduates. International Journal of Offender Therapy and Comparative Criminology, 120. https://doi.org/10.1177/0306624X17735041

Hayes, J., \& Blunt, C. (2011). Review of Offender Learning. London.

Ibrahim, I. A. A., \& Mohamed, M. S. A. (2017). Educational Management , Educational Administration and Educational Leadership: Definitions and General concepts SAS Journal of Medicine ( SASJM ) Educational Management , Educational Administration Leadership: Definitions and General concepts and. https://doi.org/10.21276/sasjm.2017.3.12.2

Ifeanyichukwu, O., \& Abuchi, U. K. (2015). The Role of Formal Education in the Rehabilitation and Reintegration of Prisoners in Nigeria: A Case Study of

22 | JISAE. Volume 6 Number 1 February 2020. 
Jos. Journal for Studies in Management and Planning, 01(11), 43-54.

Justice's, U. S. D. of. (2016). U . S . Department of Justice Report and Recommendations Concerning the Use of Restrictive Housing.

Kielmann, K., Cataldo, F., \& Seeley, J. (2012). Introduction to Qualitative Research Methodology: A Training Manual. Malawi: Department for International Development (DfID).

Krezmien, M. P., Mulcahy, C. A., \& Leone, P. E. (2008). Detained and Committed Youth: Examining Differences in Achievement, Mental Health Needs, and Special Education Status, 31(4), 1-20. https://doi.org/10.1353/etc.0.0029

Liu, C., \& Zhang, X. (2015). Critically Analyse the Contribution Made by Qualitative Research to ELT ( English Language Teaching) in China. International Journal of English Language Teaching, 2(2), 45-55. https://doi.org/10.5430/ijelt.v2n2p45

Lukum, A. (2015). EVALUASI PROGRAM PEMBELAJARAN IPA SMP MENGGUNAKAN MODEL COUNTENANCE STAKE Astin Lukum Universitas Negeri Gorontalo. Jurnal Penelitian Dan Evaluasi Pendidikan, 19(1), 25-37. https://doi.org/10.21831/pep.v19i1.4552

MacDonald, M. (2018). Overcrowding and the impact on prison conditions and health. International Journal of Prisoner Health, 14(2), 2-6. https://doi.org/10.1108/IJPH-04-2018-0014

Makovec, D. (2018). The Teacher's Role And professional Development. International Journal of Cognitive Research in Science, Engineering and Education, 6(2), 33-45. https://doi.org/10.5937/ijcrsee1802033M

Maphoso, L. T., \& Mahlo, D. (2015). Teacher Qualifications and Pupil Academic Achievement. J. Soc Sci, 42(1,2), 51-58. https://doi.org/10.1080/09718923.2015.11893393

Meissner, P., \& Jourdan, M. (2017). Roadmap for the Development of Prisonbased Rehabilitation Programmes. Vienna: United Nations Office.

Michals, I., \& Kessler, S. (2015). Prison Teachers and Their Students: A Circle of Satisfaction and Gain. Correctional Education Association, 66(3), 47-62. https://doi.org/10.2307/26508011

Musau, L. M., \& Abere, M. J. (2015). Teacher qualification and students ' academic performance in science mathematics and technology subjects in Kenya, 7(3), 83-89. https://doi.org/10.5897/IJEAPS2014.0386

Najih, M. (2018). Indonesian Penal Policy: Toward Indonesian Criminal Law Reform Based on Pancasila, 3(02), 149-174. https://doi.org/https://doi.org/10.15294/jils.v3i02.27510

Németh, J., \& Long, J. G. (2012). Assessing Learning Outcomes in U . S . Planning Studio Courses. Journal of Planning Education and Research, $x x(\mathrm{x}), 1-15$. https://doi.org/10.1177/0739456X12453740

Novian, R., Eddyono, W. S., Kamilah, G. A., Dirga, S., Nathania, C., \& Napitupulu, A.T.Erasmus Wiryawan, Martanto Syahrial Budhiman, A. A. (2018). Strategi Menangani Overcrowding di Indonesia: Penyebab, Dampak Dan Penyelesaiannya. Jakarta: Institute for Criminal Justice Reform (ICJR).

Palardy, G. J., \& Rumberger, R. W. (2015). Teacher Effectiveness in First Grade: The Importance of Background Qualifications, Attitudes, and Instructional 
Practices for Student Learning Gregory. Educational Evaluation and Policy Analysis, 30(2), 111-140. https://doi.org/10.3102/0162373708317680

Pasupathi, M., \& Mclean, K. C. (2012). Processes of Identity Development: Where I Am and Processes of Identity Development: Where I Am and How I Got There, 8-28. https://doi.org/10.1080/15283488.2011.632363

Patrie, N. (2017). Learning to be a Prison Educator. Journal Of Prison Education and Reentry, 4(1), 17-32. https://doi.org/10.15845/jper.v4i1.1050

Prabha, S. (2016). Laboratory Experiences for Prospective Science Teachers : A Meta-analytic Review of Issues and Concerns. European Scientific Journal, 12(34), 235-250. https://doi.org/10.19044/esj.2016.v12n34p235

Rahmawati, D., \& Anggraini, A. D. (2017). Evaluasi Program Kurikulum Berdasarkan Standar Isi, Standar Proses, dan Standar Kompetensi Lulusan di SDN PISANGAN TIMUR 10 PAGI, 5(1), 35-50. https://doi.org/10.21009/JPEB.005.1.3

Relisa. (2016). KAJIAN PRASARANA PENDIDIKAN SEKOLAH DASAR SEBAGAI SALAH SATU INDIKATOR PENCAPAIAN STANDAR NASIONAL PENDIDIKAN STUDY OF PRIMARY SCHOOL INFRASTRUCTURE AS ONE OF INDICATOR IN. Jurnal Pendidikan Dan Kebudayaan, 1(19), 81-96.

Russell, C. B., \& Weaver, G. C. (2008). Student Perceptions of the Purpose and Function of the Laboratory in Science: A Grounded Theory Study. International Journal for the Scholarship of Teaching and Learning, 2(2), 114. https://doi.org/10.20429/ijsotl.2008.020209

Sajidan, R. nat., Baedhowi, Triyanto, Masykuri, \& Mohammad, S. A. T. (2018). Peningkatan Proses Pembelajaran Dan Penilaian Pembelajaran Abad 21 Dalam Meningkatkan Kualitas Pembelajaran SMK (Mohamad He). Indonesia.

Shen, J., Poppink, S., Cui, Y., \& Fan, G. (2007). Lesson Planning : A Practice of Professional Responsibility and Development. Educational Horizons, 248260. Retrieved from https://files.eric.ed.gov/fulltext/EJ772517.pdf

Shinkfield, A. J., \& Graffam, J. (2010). The Relationship Between Emotional State and Success in Community Reintegration for Ex-Prisoners. International Journal of Offender Therapy and Comparative Criminology, 54(3), 346-360.

Silvestri, A., \& Wdizioni, A. (2013). Prison conditions in the United Kingdom. Roma: Association Antigone Onlus.

Siswanto, S. (2019). Penerapan Model Evaluasi Stake (Countenance) Untuk Mengevaluasi Pembelajaran Dasar - Dasar Akuntansi. Jurnal Pendidikan Akuntansi Indonesia, 8(1), 10-18. https://doi.org/10.21831/jpai.v8i1.940

Sulhin, I. (2017). Filsafat Pemasyarakatan dan Paradoks Pemenjaraan di Indonesia. Punishment, Penology, Pemasyarakatan, Criminology, (November), 1-19.

Uche, G. N. (1995). Vocational training for prison inmates: a treatment model. International of Lifelong Education, 14(5), 365-374. https://doi.org/10.1080/0260137950140503

Urombo, L., \& Kasimba, R. (2018). Factors behind Recidivism at Chikurubi Farm Prison in Zimbabwe. Journal of African Foreign Affairs (JoAFA), 5(3), 103118. https://doi.org/https://doi.org/10.31920/2056-5658/2018/v5n3a6

24 | JISAE. Volume 6 Number 1 February 2020. 
Utami, P. N. (2017). Keadilan bagi narapidana di lembaga pemasyarakatan (Justice for Convicts at the Correctionl Institutions). Jurnal Penelitian Hukum DE JURE, 17(3), 381-394. https://doi.org/http://dx.doi.org/10.30641/dejure.2017.V17.381-394

Vandeyar, S. (2017). The Teacher as an Agent of Meaningful Educational Change. Education Sciences: Theory \& Practice, 17(2), 373-393. https://doi.org/10.12738/estp.2017.2.0314

Vanitha Thanabalan, T., Siraj, S., \& Alias, N. (2015). Evaluation of a digital story pedagogical module for the indigenous learners using the stake countenance model. Social and Behavioral Sciences, 176, 907-914. https://doi.org/10.1016/j.sbspro.2015.01.557

Xhemajli, A., Cyril, S., \& Methodius. (2016). The Role Of Teacher In Interactive Teaching. International Journal of Cognitive Research in Science, Engineering and Education, 4(1), 31-38. https://doi.org/10.5937/IJCRSEE1601031X

Zulfiati, \& Kurniawati. (2018). Evaluasi Program Pembelajaran Sejarah Terintegrasi dalam Mata Pelajaran IPS Di SMPN 4 Kota Bekasi. Jurnal Pendidikan Sejarah, 7(1), 1-28. https://doi.org/10.21009/JPS.071.01 